\title{
Chapter 27 \\ Healthy Fisheries Sustain Society and Ecology in Burkina Faso
}

\author{
Andreas Melcher, Raymond Ouédraogo, Otto Moog, Gabriele Slezak, \\ Moumini Savadogo, and Jan Sendzimir
}

\subsection{Introduction}

\subsubsection{The Challenges of Sustaining a Fishery in Burkina Faso}

Burkina Faso (BF) is a Sahelian country located in West Africa on the arid southern rim of the Sahara. In this region all work and movement revolve around water and its availability, whether in nature or society. The aquatic ecosystems responsible for storing and replenishing the quantity and quality of water are vital for the productivity

\footnotetext{
A. Melcher $(\bowtie)$

Institute of Hydrobiology and Aquatic Ecosystem Management, University of Natural Resources and Life Sciences, Vienna, Austria

Centre for Development Research, University of Natural Resources and Life Sciences, Vienna, Austria

e-mail: andreas.melcher@boku.ac.at

R. Ouédraogo

Institute for Environment and Agricultural Research (INERA), Ministry of Higher Education, Scientific Research and Innovation, Ouagadougou, Burkina Faso

O. Moog · J. Sendzimir

Institute of Hydrobiology and Aquatic Ecosystem Management, University of Natural

Resources and Life Sciences, Vienna, Austria

e-mail: otto.moog@boku.ac.at; jan.sendzimir@boku.ac.at

G. Slezak

Department of African Studies, University of Vienna, Vienna, Austria

e-mail: gabriele.slezak@univie.ac.at

M. Savadogo

IUCN International Union for Conservation of Nature, IUCN Burkina Faso Office,

Ouagadougou, Burkina Faso

e-mail: moumini.savadogo@iucn.org
} 
and food security of all flora and fauna as well as all society, whether nomadic herdsmen, sedentary farmers, or urban workers. The rising contribution of fish to provide protein in the diet has only increased the importance of managing fish and the aquatic landscapes they depend on. However, achieving sustainable fisheries is complicated by threats to productivity (more frequent droughts in a drying climate) and consumption (record population growth rates), as well as governance constraints.

Ranked in the bottom 5\% of all developing countries (UNDP 2015), the urgent need for sustainable development in BF is challenged by severe socioeconomic and natural constraints. In the latter case, chronic water scarcity is interrupted by episodes of severe drought that continue for multiple years. However non-drought years can scarcely replenish the water deficit because too little of the meager rain that falls is retained long enough to help drive the processes supporting ecosystems and society. During the brief rainy season (4 months on average), precipitation occurs with very high variability in space and time and with such intensity that runs off often exceeds percolation, and groundwater levels are not replenished (Filippi et al. 1990; Wang et al. 2010; Pavelic et al. 2012).

Socioeconomic challenges constrain development with multiple factors: one of the highest population growth rates in a nation that already has seven times as many people as a century ago (INSD 2006) and poor access to either financial or human capital, e.g., almost half the people at poverty level and only $31 \%$ of children complete primary school (MEF 2004). As a result, famine is recurrent, and chronic malnutrition affects $44.5 \%$ of 5 -year-old children and $13 \%$ of the women of childbearing age. This makes food security central to national development policies and strategies (DGPSA 2007). Fisheries are also linked to wider security issues in that political instability and associated terror attacks from northern neighbors, e.g., Mali and Niger, curtail efforts to monitor and manage aquatic ecosystems, especially along the northern tier of BF.

\subsubsection{Addressing Those Challenges Through the SUSFISH Project}

In 2011 the SUSFISH project funded by the Austrian Development Agency was launched to build the basis in science and policy for sustainably managing natural and man-made aquatic systems in BF. This involved building scientific capacity to monitor and assess the dynamics of ecosystem services (fish, water, self-purification capacity) provided by aquatic ecosystems, the educational capacity to train scientists and technicians in these concepts and methods, and institutional capacities in management and policy formulation, all of which are linked with research and education in the sphere of water and fisheries in BF (Melcher 2015; Ouedraogo et al. 2015; Slezak et al. 2015).

The SUSFISH project established the capacity to manage fisheries by applying the latest scientific methods in a joint partnership between Austrians and Burkinabe. 


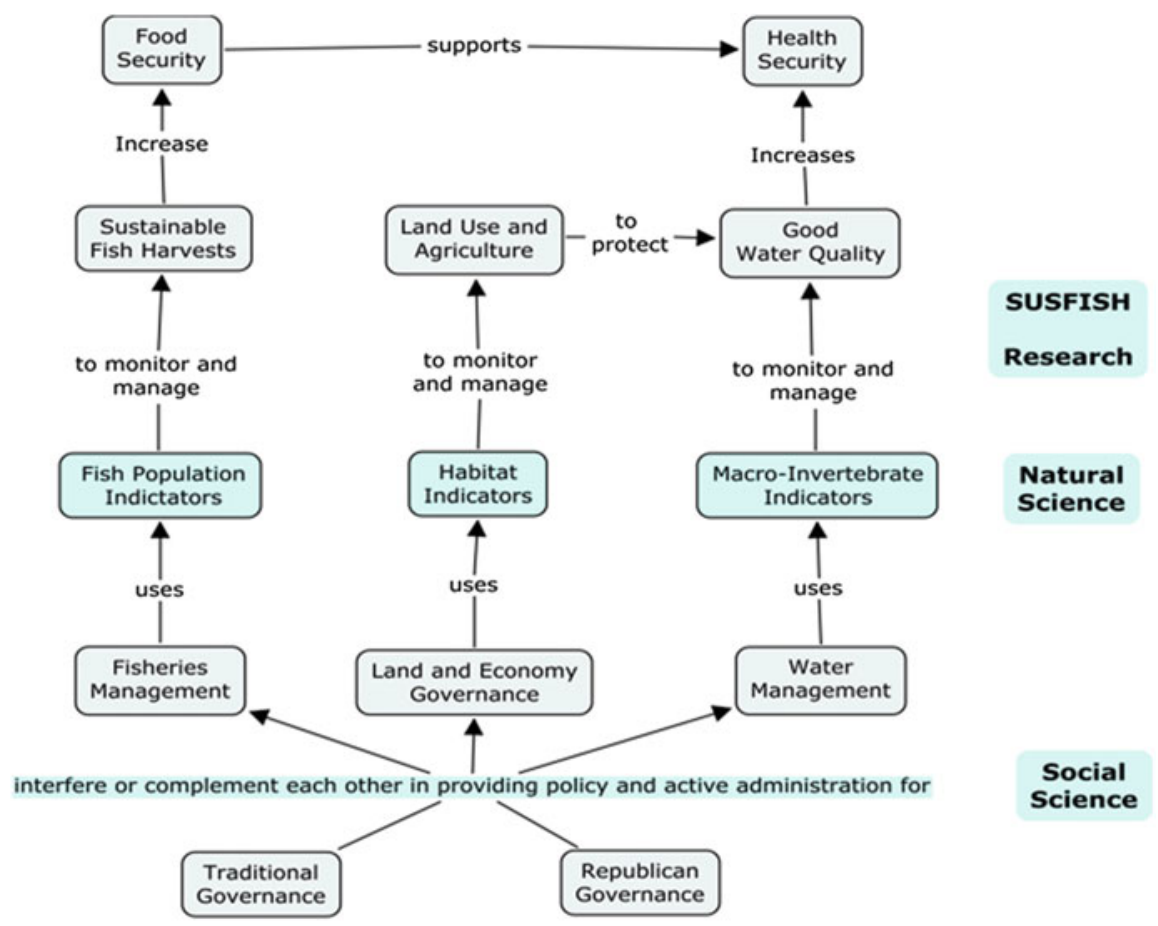

Fig. 27.1 SUSFISH project integration of research and policy goals in support of sustainable management of fisheries and aquatic ecosystems in BF (after Ouedraogo et al. 2015)

Global standards in statistical modeling were applied to rigorously establish bioindicators as management tools that link sets of species (fish and benthic invertebrates) with water quality parameters (Fig. 27.1), implemented by stakeholders involved in the SUSFISH project. However, these sustainability challenges are wider than ecology. For example, artificial aquatic ecosystems like reservoirs are novel landscape elements that alter the social, cultural, and economic features of local communities and their approaches to natural resources management. In Burkina resource users pursue fish conservation with little governmental support (Butterworth et al. 2010), but little is known as to how far local people can assume responsibility to manage waters and fish (Ouedraogo 2010). Fishing communities remain poor despite the emergence of fishing income to complement their many other economic activities. Furthermore, despite research over the past decade, e.g., the Sustainable Fisheries Livelihoods Programme in West Africa (FAO IDAF; e.g., Fabio et al. 2003), much research remains to understand their livelihoods and food security strategies as professional groups, households, and individuals. In addition, development research in Africa has a tragic history of narrowly focusing on technical methods whose use terminates with the end of each project and never become integrated into the policy and practice of society (Raynaut 1997; Batterbury and Warren 2001). Even if the capacity to monitor fisheries does become established, the 
reasons why fisheries became unproductive and might remain so may originate from a range of sources both natural and social.

To identify and explore the barriers and bridges to that integration, a range of social and systems sciences were applied to examine the effectiveness of "republican," e.g., national, based on the French system, and traditional forms of governance and the potential to harmonize them. In addition, exercises in scenario development allowed managers and planners to explore potential paths of policy development. Finally, conceptual modeling afforded a systems analysis of the ecological, economic, and social factors that can individually or by interaction create opportunities or barriers to sustainable fisheries management. The results were used to make recommendations for fish and water policies, in education (universities and governmental agricultural professional schools), and will have practical relevance for food security and health care (Melcher et al. 2013; Ouedraogo et al. 2014; Sendzimir et al. 2015).

This chapter pursues the central question of the SUSFISH project, e.g., what is the long-term potential to establish sustainable fisheries and aquatic ecosystems on which they depend in BF? SUSFISH embraced this question as a challenge wider than simply transferring the technical means to monitor fisheries but in instilling and awakening a culture of healthy fisheries that is broadly supported across Burkinabe society as well as in government policy. We begin by describing the scientific advances that the project used in application to establish bioindicators and monitoring methods as the technical base of fisheries management. We then consider the many factors, biophysical as well as economic, political, and cultural, which potentially can influence the trajectory of Burkinabe fisheries toward sustainability. We conclude with recommendations based on lessons learned.

\subsection{Description of the Aquatic Resources in BF and Its History}

$\mathrm{BF}$ is located in the heart of West Africa in the sub-Saharan region $\left(12^{\circ} 16^{\prime} \mathrm{N}\right.$, $2^{\circ} 4^{\prime} \mathrm{W}$ ) (Fig. 27.2). The climate is tropical semiarid, with ambient air temperature averaging around $28.8{ }^{\circ} \mathrm{C}$ and temperature extremes vary between 24 and $40{ }^{\circ} \mathrm{C}$ (Ly et al. 2013). The region is marked by a south to north gradient of increasing aridity as evapotranspiration (1700-2400 mm/year) exceeds annual precipitation $(400-1200 \mathrm{~mm})$ in each of three eco-regions (MECV 2007). Precipitation is extremely variable in space and time over the rainy season (May/June to September), and often such intense bursts run off rather than percolate into the groundwater. As a result, some water courses are intermittent, lying dry and dormant for weeks to months at a time (Ouedraogo 2010).

To meet the growing demand for water amid chronic water scarcity, more than 1400 reservoirs were built since 1950, making Burkina a leading country in water resource development (Ouedraogo 2010) and governance (Niasse et al. 2004). Reservoirs account for $82 \%$ of the surface water (SP/CONAGESE 2001) and are 


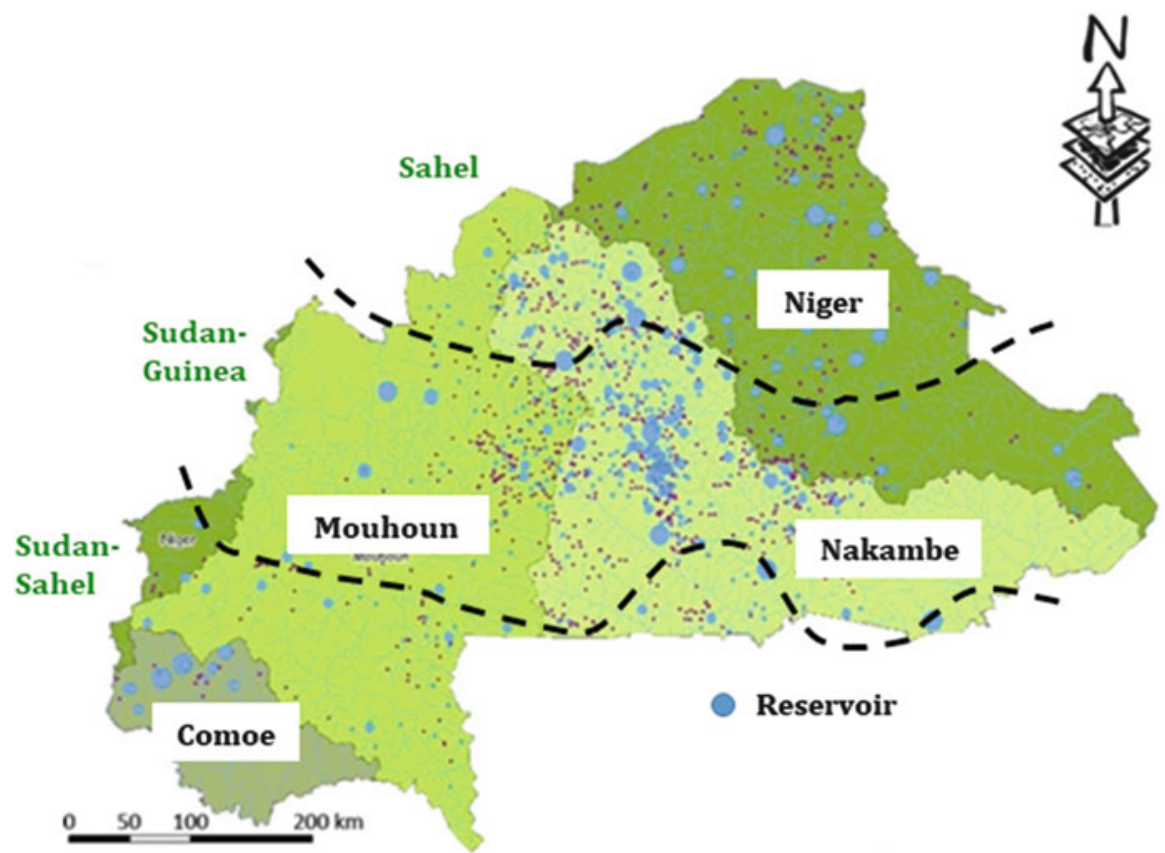

Fig. 27.2 Map of reservoirs and their size in all four river basins of BF, Comoe, Mouhoun, Nakambe and Niger and the three eco-regions, Sahel, Sudan Guinea and Sudan Sahel, reflecting increasing latitude of the country (Adapted from Cecchi et al. 2009)

used mainly for agriculture, livestock breeding, and fishing. Reservoir construction spurred 15-fold growth in fisheries harvests since 1950, employing more than 30,000 fishermen and the several thousand women involved in processing and selling fresh fish (Zerbo et al. 2007). Hence, fishing is an emerging socioeconomic activity that contributes significantly to household livelihoods. Typically a fisherman earns $40 \%$ of his livelihood from fishing and the remaining 60\% from agriculture (rain fed and irrigated) and livestock breeding (Ouedraogo 2010). A woman fish processor earns about US\$17/month (Zerbo et al. 2007), which is also above the absolute poverty threshold.

The fisheries and the aquaculture sectors in BF (MRAH 2013; Stratégie Nationale de Développement Durable de la Pèche et de l'Aquaculture à l'Horizon 2025 "National Strategy for Sustainable Development of Fisheries and Aquaculture") are increasingly productive. The total fish capture in BF is estimated at 12,000 tons and aquaculture at $400 \mathrm{~T}$. The sector employs 32,700 fishermen, 5700 sellers, and 3000 fish processors and contributes to less than $1 \%$ to the GDP. BF imports more than 44,400 $\mathrm{T}$ of fish annually.

However, high water demands and low management capacity had led to overuse of surface waters. Rising water demand combined with severe sedimentation rates are depleting reservoir water volumes to the point where some reservoirs may disappear within 25 years (Ouedraogo 2010). In addition, rising fishing pressures have resulted 
in overfishing that depletes fish stocks in terms of total population number, biodiversity, and average fish size. Fish size is a critical indicator of fish reproductive capacity and hence the sustainability of fish populations, which is further threatened by declining water quality as expanding urban centers dispose of waste in rivers and their tributary creeks and canals. This is particularly the case for the nation's capital, Ouagadougou, whose rapid expansion outstrips treatment capacity. Hence, all waste is thrown into the catchment of the second most important river in BF, the Nakambe River, which hosts $40 \%$ of the dams and $35-40 \%$ of the population. These pressures increase food security risks in river systems (Cook et al. 2009) leading to multiple fish extinctions (Ouedraogo 2010). According to the IUCN Red list settings, 26.3\% of the West African freshwater fish species face extinction because of pollution, deforestation, sedimentation, mining, and agriculture (Smith et al. 2009). To establish the basis to track how the status of aquatic resources changes in response to these threats, the SUSFISH project carried out literature and field surveys to assemble historic and current data into a national database (Mano 2016).

\subsection{Diversity and Conservation Status of Aquatic Species}

The inland waters of Western Africa support a high diversity of aquatic species with high levels of endemism. Estimated numbers of inland water-dependent species by major taxonomic group in West Africa: 563 fishes, 90 mollusks, 287 odonates, and 35 crabs representing 2-5\% of global described species (Smith et al. 2009; IUCN 2016). More than $14 \%$ of species across the region are currently threatened, and future levels of threats are expected to rise significantly due to a growing population and the corresponding demand of natural resources. Threatened species, comprising critically endangered (endangered and vulnerable), are estimated at 26\%, 9\%, 18\%, and $40 \%$ for fishes, mollusks, odonates, and crabs, respectively.

\section{Fish}

At the national level, under the SUSFISH project, we collated a total of 152 species from 28 families described so far, from which 145 have been assessed according to the criteria of IUCN Red List (Ouedraogo et al. 2016). The results indicate that $20.7 \%$ of the 145 evaluated species are threatened, of which $1.4 \%$ are critically endangered, $4.8 \%$ are endangered, and $14.5 \%$ are vulnerable. These proportions are comparable to the West African evaluation results (26\%) from the IUCN Red List (Smith et al. 2009). One key finding is the vital role of protected sites as refuges for most of the threatened species. This highlights the importance of sustaining the health of protected areas, by protecting the surface water streams that irrigate them. Another finding is overall conservation assessment undermined by the large fraction of species with data deficiency (28.3\%). Most such species have rarely been seen since their description in the 1960s by Roman (1966), so their conservation status remains uncertain. Finally, given the intensification of the different human-related and climatic pressures, the appeal for more rigorous conservation-related actions is in no way diminished by the relatively high $(40.7 \%)$ proportion of species of least concern. 
Fig. 27.3 Number of exclusive and shared fish species between four main sampling sites (after Meulenbroek 2013)

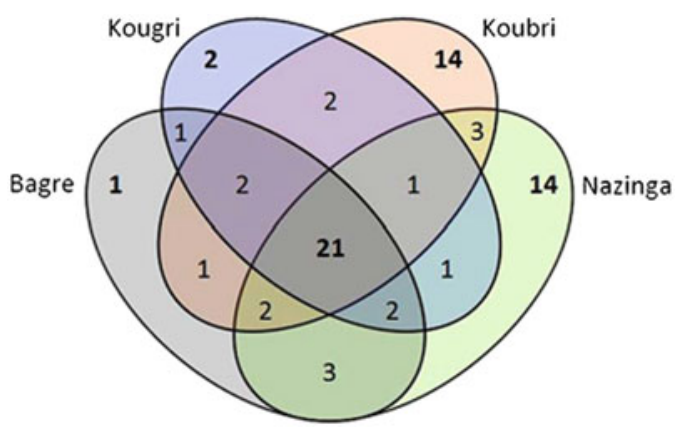

Within the SUSFISH project, 68 species, 41 genera, and 19 families were collected in seven sampling areas in the Upper Volta catchment. Cyprinidae, Alestidae, Mormyridae, and Mochokidae were the most represented families in terms of species and individual number. Oreochromis niloticus, Tilapia zillii, Brycinus nurse, Clarias anguillaris, Sarotherodon galilaeus, and Barbus macrops were the constant species. One part, species richness increased from downstream to upstream with, respectively, 14 and 2 exclusives species. Fig. 27.3 illustrates how local fish species diversity reflects low (Nazinga, Koubri) and high (Bagre, Kougri) human-induced impacts.

\section{Benthic Invertebrates}

The current knowledge of benthic macroinvertebrates in African rivers is comparatively fragmentary and restricted to a few countries, primarily in Eastern and Southern Africa. In West Africa, only a few studies treat the macroinvertebrate fauna, e.g., Aggrey-Fynn et al. (2011) in Ghana, and Camara et al. (2012) and Edia et al. (2013) in Ivory Coast. Some initial efforts have tested the relationship of benthic invertebrate diversity to pollution in Ghana (Thorne and Williams 1997) and in Gabon (Vinson et al. 2008). Recent SUSFISH project publications increased the knowledge base of benthic invertebrates in BF (Trauner et al. 2013; Koblinger and Trauner 2014; Kaboré 2016).

Benthic invertebrate communities in the running waters of BF exhibit a taxonomic gradient that is characterized as follows: insects $>$ mollusks $>$ annelids $>$ crustacea $>$ arachnids. According to Kaboré et al. (2016a), the rivers in the Volta and Comoé catchment are dominated by insects (relative abundance of $95 \%$ ), represented mostly (80\%) by midges and flies (Diptera). The mayflies (Ephemeroptera) and caddies flies (Trichoptera) made up $7 \%$ of the abundance. The Plecoptera as well as the Bivalvia, Ostracoda, and Arachnida were found in frequencies lower than $0.5 \%$. With respect to the taxonomical composition, a total of 132 taxa was recorded, and the large majority of these (103 taxa) belonged to 57 families from eight orders of insects.

In a study on the water beetles of BF, Kaboré et al. (2016b), a total of 38 species of diving beetles (11 Noteridae and 27 species of Dytiscidae) and 22 species of water scavenger beetles Hydrophilidae could be detected from 18 lentic and lotic water 
bodies. The fact that out of these 60 water beetle species 24 species have been reported for the first time in BF indicates clearly that the taxonomic knowledge of benthic invertebrates is at its infancy in $\mathrm{BF}$.

\subsection{Human-Induced Impacts}

New knowledge generated by SUSFISH field research serves as a foundational database that can inform the formulation and implementation of policy for managing aquatic resources. It provides benchmark data from which to measure progress and set target performance levels for policy and practice. For example, not only has SUSFISH research generated the most current and comprehensive species lists for $\mathrm{BF}$, it has identified the significance of the relative scarcity of some of its species: a significant fraction (56\%) of fish species in Burkina is threatened. SUSFISH has established the data basis to identify the multiple sources of those threats and quantify their impacts on aquatic species. Broadly, in BF the presence, diversity, trophic level, density, and biomass of certain fish and benthic invertebrate genera and species respond negatively to a range of anthropogenic pressures (Ouedraogo 2010; Melcher et al. 2012; Stranzl 2014; Kaboré et al. 2016a; Kaboré 2016; Mano 2016).

\section{Using Biological Indicators to Distinguish Impacted and Nonimpacted Areas} Approaches that follow Moog and Stubauer (2003), Nijboer et al. (2004), or Pont et al. (2006) to identify "a priori criteria" from distinct areas were applied in BF to understand human impacts on aquatic resources and to describe reference conditions based on physicochemical features, hydro-morphology and in-stream structures, and land use. We found that protected areas can reasonably be considered as credible reference sites as far as they show low impact levels. Benthic invertebrates as well as fish taxa respond not only to threats and pressures but also to landscape and habitat parameters. As such, certain genera and species can be useful as bioindicators of water body typology and river morphology and structure in BF catchments as well as land use-land cover and habitat-type parameters. Kaboré (2016) investigated the benthic macroinvertebrate communities of 66 areas at Sahel Rivers and found that a multimeric index approach could be developed to assess the ecological quality of running water bodies.

The practical implications of SUSFISH research are that it provides specific knowledge about the sensitivity of certain fish and benthic invertebrate taxa to specific pressures and/or clusters of pressures that offer the data basis for monitoring the presence and impacts of pressures. Overall, SUSFISH surveys demonstrate that such parameters as fish size, abundance, and diversity are related to the quality of fisheries and habitat management. Therefore, both fisheries and water resources can be better managed based on science that rigorously monitors and manages multiple levels: the aquatic taxa, the water column, the habitat quality and surrounding land uses, and the human activities that generate pressures impacting these aquatic and terrestrial habitats. SUSFISH data indicate that fish management must be informed 
Fig. 27.4 Increasing number of human-induced impacts (Global pressure index) show the dramatic decline of the number of fish species for each of the main sampling sites in terms of number of fish species (after Stranzl 2014)

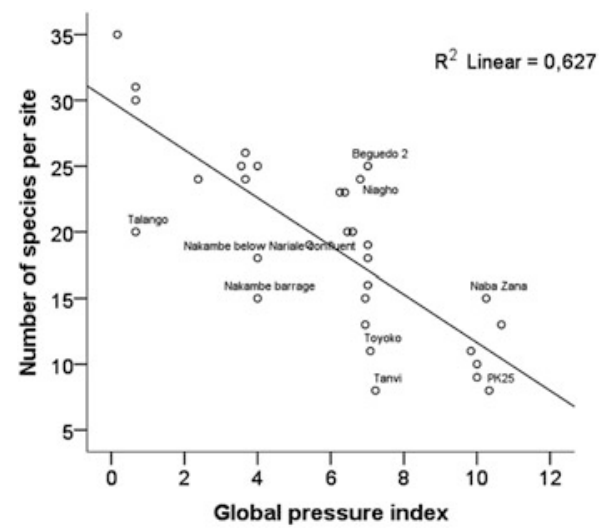

by data at scales larger than landscape, since fish biodiversity is related to their mobility and, ultimately, to water network connectivity (Ouedraogo 2010; Melcher et al. 2012; Stranzl 2014; Kaboré et al. 2016a; Kaboré 2016; Mano 2016).

In general, fish taxa exhibit lower numbers and body mass as human-induced impacts increase (Fig. 27.4). More specifically, fish taxa can be used as bioindicators of the impacts of anthropogenic pressures either in the positive or negative sense. For example, Stranzl (2014) and Mano (2016) concluded that Auchenoglanis gen. and Hydrocynus gen. could be used as sentinel genera because they are not found in areas of high anthropogenic impact. Clarias sp. and Sarotherodon sp. increase with pressures, unlike other species, e.g., Alestes sp. and Schilbe sp., which are sensitive and decrease in number as pressures rise. Hemichromis and, especially, Tilapia correlate positively with hydro-morphological pressure, but they respond negatively to chemical impacts.

\subsection{Adaptive Governance of BF Fisheries}

The SUSFISH project took the first concrete steps toward establishing a governance framework that can adaptively reestablish and manage sustainable fisheries in BF. These steps provided first the tools to identify the status of aquatic ecosystems in general and their component fish and benthic invertebrate fauna in particular. Application of these tools demonstrated that these fauna could be used as reliable bioindicators of aquatic ecosystem conditions and anthropogenic pressures impacting those ecosystems. Therefore, the first phase of SUSFISH proved that such tools can help to measure progress toward sustainability in managing fisheries. 
The second phase of SUSFISH worked to identify which factors in nature and society help or hinder the said progress toward food security in BF. That means that beyond the technical tools, what needs to be done to establish a "shared understanding of sustainable fisheries in society" in BF? Surveys were conducted at two levels. In the field, practitioners whose livelihoods depended on the fisheries food chain in $\mathrm{BF}$ were interviewed. In work centers of science and policy in Ouagadougou and Bobo-Dioulasso, expert scientists and policy makers met in workshops to identify what scenarios of future development of aquatic ecosystems are of concern to management and to explore the variables and relationships that might determine the trajectory of these scenarios.

\subsubsection{Scenarios of Declining Fishery Sustainability}

Most of the potential pathways of fishery decline envisioned by experts resulted from interactions between biophysical factors. The salient trajectory of concern is that overfishing has driven fisheries into a trap that only extreme policies, e.g., prolonged shutdown of fishing, could liberate it from. In this scenario, overfishing drives down the average size of adult fish and, hence, the productivity of the whole fishery, since egg production is proportional to body mass. Sustained overfishing of an underproductive fishery could eliminate any chance of rebounding to its original productive potential. A number of scenarios explore potential consequences of excessive or abusive use of resources and habitats in and around aquatic ecosystems. Of particular concern is water extraction due to (gold) mining, which often is not strictly regulated because of its elite status as the main source (48\%) of export earnings (Ouedraogo 2010; IMF 2014). At the end of the dry season, water volumes can decline below thresholds critical to fish capacity to survive and reproduce in the wet season.

The most ubiquitous human pressure is agriculture. It is the national economic mainstay found in every catchment whether in the arid Sahelian steppe in the north (animal husbandry) to the Northern Sudanian savanna that exists as a band across the nation's center [cotton, groundnuts, karite (shea nuts), and sesame] to the moister Southern Sudanian savanna in the southwest (sugar). Both agriculture and mining practices can degrade habitats in and around aquatic ecosystems, reducing the capacities to filter runoff or provide services that sustain biodiversity. Not only does agriculture drive water demand, it also utilizes pesticides and fertilizers that can bioaccumulate in aquatic ecosystems and degrade productivity (especially the reproductive capacity of commercial fish) or shift the balance of phytoplankton to species, e.g., cyanobacteria, unpalatable to fish or increase the proliferation of macrophytes and thereby reduce the capacity to catch fish. However, in the latter case, macrophyte proliferation might also help reduce overfishing and provide more nursery habitat in aquatic ecosystems. 
Evidence from field research makes several of the scenarios associated with habitat degradation appear likely. Increasing intensity of anthropogenic pressures leads to declines in (1) diversity, (2) some (potential indicator) species and also families, (3) trophic level (the trophic level dropped from 3 to 2.5 at highly impacted sites.) based on a trophic level scale by (Pauly et al. 2000), and (4) density and biomass of intolerant species. The number of fish genera was found to decline with the number of pressures. Anthropogenic pressures on fisheries mostly occur in multiple forms (clusters) and correlate among each other to create "cumulative effects." Agricultural pressures were present in $87 \%$ of our sites. $70 \%$ of all sites exhibited bad water quality (expert opinion). $50 \%$ had connectivity pressures (GIS); stream morphology is mostly still ok (SS). In the Nakambe catchment, only $13 \%$ of the area remained as natural vegetation. $76 \%$ is cultivated land, and $11 \%$ is bare soil, and water holding capacity has decreased $33 \%$ in 30 years.

Two scenarios explore how the productive potential for reservoir fisheries can be limited by water volume lost to sedimentation or degradation of infrastructure, e.g., dikes and spillways. Lower water volumes have less capacity to buffer temperature increases or inputs of toxic chemicals and are more likely to cause fisheries productivity to decline. Productivity could be limited also if fish population declines due to harvesting could not be replenished by migration of fish from regional metapopulations. Fish migrations could be blocked when regional hydrographic networks of rivers are disrupted by overbuilding of dams without infrastructure to allow fish to bypass. This latter scenario is supported by evidence showing that study sites that are under anthropogenic pressure but have intact connectivity, e.g., fish can migrate to other parts of the water network, have a higher diversity than fragmented ones. This may be related to our observation that about $50 \%$ of all caught species are potamodromous and therefore normally migrate for spawning. Connectivity is severely impacted by hydrograph modification and reservoir dams. More than $90 \%$ of the annual discharge in the Nakambe basin is held back by dams, causing massive hydrographical modification. Approximately $89 \%$ of all sites in this study were regarded as under influence of hydrographical changes.

Several scenarios illustrate the potential for social, cultural, and political factors to limit fisheries productivity. One posits that fish harvests and habitat maintenance are substandard because most fishermen have inadequate skill sets. There may have been insufficient time to develop institutions for training, since fishing has only become common in recent decades. In our field data, learning fishing methods over generations contextualized in the environmental challenges was found only in a few cases. In addition, fisheries may not be productive enough to support enough fishermen full time, so fishing is mostly a part-time job for farmers and herdsmen. Another scenario posits that indigenous fisheries have been neglected because international markets have very quickly filled the majority $(80 \%)$ of national demand. Similarly, failure to develop functioning institutions at all levels may arise when neglect from the national level and decline at the local level erode any trust that fisheries governance can successfully be established. 


\subsubsection{Socioeconomic Factors Influencing Fishery Sustainability}

As previously noted, SUSFISH was founded in recognition of the history of failure of development projects grounded only on technical and/or scientific advances. In $\mathrm{BF}$ alone we found examples of failure to adopt modernizing technology in the form of abandoned equipment and infrastructure (fish ponds, refrigerators, fish weighing scales, fish shops). For that reason SUSFISH sponsored research into the social, economic, and political barriers and bridges the gap to sustainable fisheries. Our research indicates that, while some encouraging examples exist, there are abundant barriers to sustainable fisheries provided by challenges of governance at multiple levels in BF.

Our results confirm that fish size and fish community diversity are associated with the degree and quality of management, both of fisheries directly and of the habitat surrounding the fishery. For example, the Nazinga site has relatively unimpacted habitat (land management) and has a closed fishing season that is well-regulated (fisheries management), and it has significantly larger fish and a higher share in adult fish than any other sampling site. Furthermore, both fish and BMI diversity are higher in protected areas, e.g., Nazinga, Mare aux Hippo than in others. Just as important to biodiversity conservation as the legal content of policy is its execution at the appropriate level (subsidiarity) by well-organized and led local actors. For example, in Moussodougou the fisheries are directly controlled by a local association that effectively enforces rules. Situations with effective management are associated with an increased biomasses and abundance with large fish specimens.

A prominent overarching challenge is that it appears that fisheries management is not equally applied all over BF but is concentrated in a few large reservoirs of "national economic interest," e.g., Ziga, Bagre, Kompienga, and Sourou. Fishing in these large water bodies is dominated by commercial fishermen, who are regulated and in good communication with government officers. However, elsewhere in BF communication is not so good for management organs devoted to smaller reservoirs, except for four fishing concessions given to the associations of the local fishermen (Bapla, Moussodougou, Tandjari, and Lera). Aside from these few examples of successful organization of local management capacity, for the most part, there are gaps between national and lower levels of governance. Briefly, a governance system that effectively functions from the central, national level out to the regional and local levels has yet to be established. Often the link between law and practices to monitor fisheries is missing (law is not adopted in practice). Therefore there is little effective police monitoring or enforcement of fishing practices at the lower levels, e.g., smaller-scale fisheries.

While efforts to decentralize management authority have been underway for years, the failure to comprehensively bridge institutions from national to local levels is hampered by the frequency of shifts of governance responsibilities (institutional nomadism) for fisheries management at the national level. One salient example of the poor communication that results from such "administrative flux" is the general 
lack of expertise that is regionally or locally available for fishermen who need expert consultation. As a result, progress in improving fishing methods is blocked by lack of capacity to learn or to organize.

In the face of poor inter-level communication and sporadic or absent monitoring, the use of illegal equipment and fishing practices only mounts. It is hard to imagine how trust in governance can be built to strengthen compliance with laws and policies under such conditions, and evidence of this eroding trust is that in some areas local fishermen have swung their allegiance from republican to traditional authorities. Traditional authorities still constitute legitimate local sources of governance. Traditional institutions play a vital role in reaffirming the identity of communities reliant on aquatic ecosystems and thereby broadly influence water and fish management. However, the current governance structure has failed to link and harmonize republican and traditional sources. And efforts to decentralize have been poorly implemented, e.g., local management committees lack the funding to even meet regularly, or have been taken over by special economic or political interests, i.e., elite capture.

The governmental bodies responsible for the fisheries sector are unaware of women's specific role in the fisheries management. Consequently they did not consider females adequately as crucial actors in their strategic and political programs. SUSFISHs sociological research on fish as an important income-generating resource shed light on women as important preserving stakeholders (e.g., systempreserving functions) in the economic, nutrition, and health domains. Interdisciplinary work revealed important cross-sectoral activities, interrelated power relations, and hindering factors that play key roles in the value chain issue of the resource fish in BF. However, notwithstanding their important economic role, since women are excluded from decision-making processes on local levels, the focus of future analysis should be oriented toward the impeding factors emerging from incomplete or misguided education, structures of associations, and power asymmetries. These findings resulted in the draft of a strategy for the integration of these aspects in the fisheries management policies, which was developed in SUSFISH.

By law there are two kinds of status of fisheries based on management type: concession and PHIE (Perimetre Halieutique d'Intérêt Economique), i.e., a fishery that impacts the national economy. But actually, there are three categories of fisheries management: very large reservoirs that never dry out and fishing continues for much of the year [PHIE; Bagré, Kompienga, Sourou, Ziga, Toécé, Douna, Yakouta, Sirba (eight reservoirs) and Lake Bam] and concessions and "others" that have no legal status. Note: subsistence fisheries exist in all three categories mentioned above. Besides this, by law there are four categories of fisheries defined according to the use of the catch: commercial, subsistence, sport, and scientific. According to SUSFISH findings, this categorization does not reflect the status quo. Besides subsistence fisheries all other categories are not represented significantly.

Into what category a fishery falls depends on how national policies are prioritized-the PHIE are "nationally important" reservoirs, whereas the latter are more "subsistence level" fishing for local markets (Fig. 27.5). For the former, management is organized at a professional level: most of the fishermen involved are professionals 


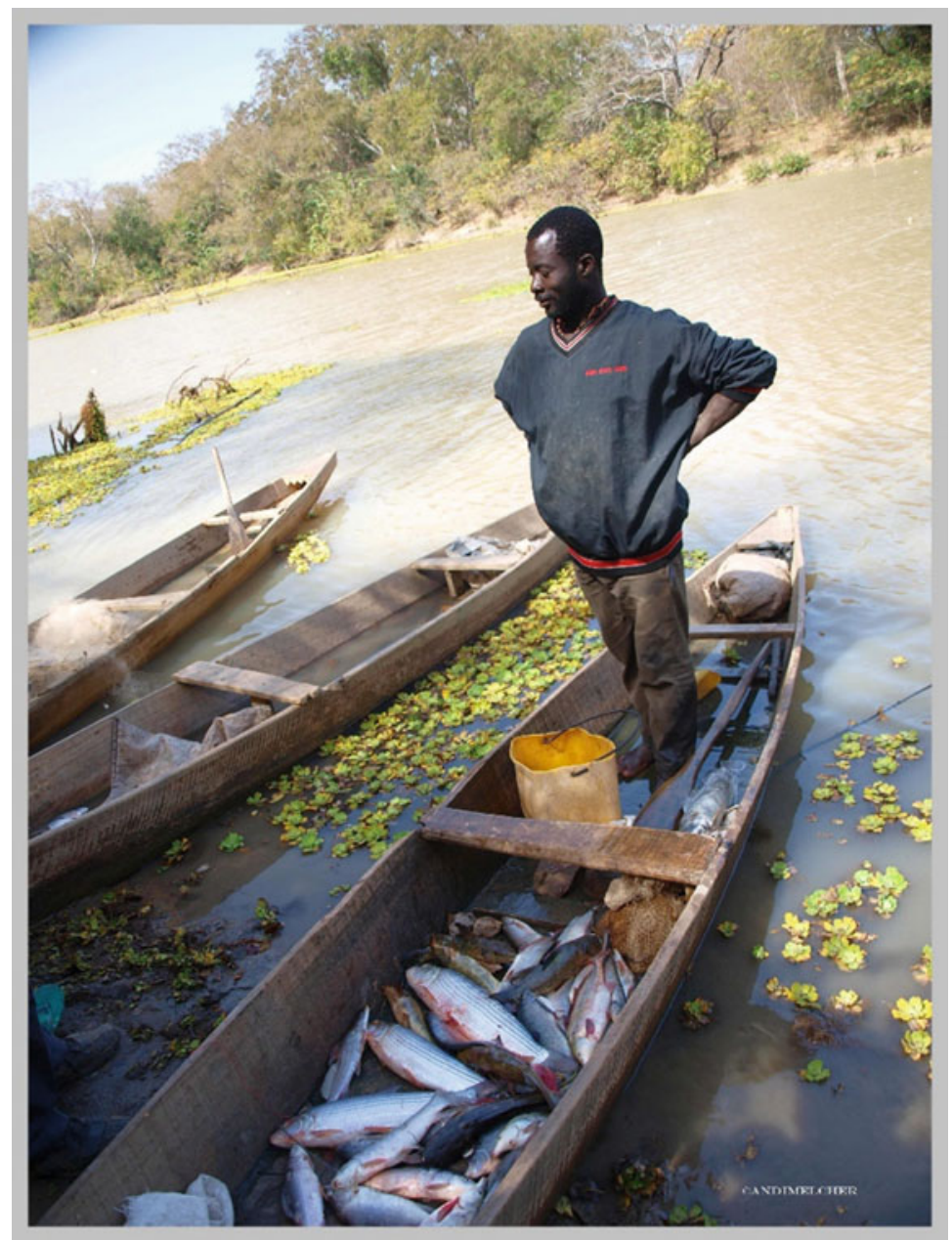

Fig. 27.5 Sustainable fishing in the protected area of Nazinga, close to the border to Ghana (Photo: A. Melcher)

and are aware of the legislation or rules. However, there is a link between education and fisheries management. As illiteracy is common among fishermen and fish processors, at a lower, more local, level awareness of regulations as well as access to information on improving fishing methods can be blocked. At the local levels (subsistence fisheries) when officials ignore rather than engage (no monitoring or enforcement) local problems, the lack of engagement gives local fishermen no opportunity to learn about fisheries policies through responding to them. Thus they remain largely uninformed about legislation and administrative policy. They do know some of the rules, but they rarely if ever observe them. Lower level agents perceive no functional links (e.g., communication) that tie GDFA staff with any of 
the decentralized lower level government layers. Therefore, most local fishermen are unaware of the GDFA or what its functions are. National legislation and policies are not known by any of the decentralized lower level government layers. In closing we must caution that this data was gathered during a transitional period (shifting responsibilities between people in different organizations) such that anyone interviewed would not claim responsibility.

\subsection{Recommendations Based on Lessons Learned}

Management of fisheries requires policies in place at the appropriate governance levels as well as reference data against which to compare policy performance over the long term. Steps must be taken to fill two gaps that prevent such management. First, there are no plans for almost all (more than 1000) minor fisheries, and only a few of the major ones have a management plan. Second, the means (equipment, training, and protocols) must be put in place and applied in as many fisheries as possible. The means to establish monitoring programs for reservoir and river fisheries all over BF have come from SUSFISH project's provision of equipment and training for surveying and monitoring as well as field data that confirm that fish and benthic macroinvertebrates can be used as bioindicators of conditions in and around aquatic ecosystems. On this basis, managers can monitor the status of fisheries and surrounding habitats as well as trends in anthropogenic impacts on aquatic fauna. Education programs for students and government agents need to be established and integrated with university research programs.

In $\mathrm{BF}$, there are a number of ways to improve the governance of aquatic resources, especially fisheries, and the sectors of society and surrounding landscapes that impact fisheries (Fig. 27.6). At the national level, efforts should be made to forge a vision of sustainable fisheries that is communicated to and made workable at all levels of society and governance. National level policy makers have failed to make a national future perspective of fisheries operative either at the federal, regional, or local levels. A national "vision" has been recorded, but it remains theory on paper, not a practical, working vision that informs policy and implementation. Failure to lead and provide a unifying vision means that local as well as regional and national actors have no paradigm of fisheries development to rally around and use as a baseline against which to measure policy performance. While indicators are lacking, evidence of failure accumulates. Infrastructure (fish ponds, refrigerators, fish weighing scales, fish shops) has been installed but either not maintained and allowed to decay or converted for private use. Such patent failures undermine trust in the government institutions that establish and execute programs, projects, and policies to develop infrastructure.

National governance of fisheries could be improved by harmonizing policies of different ministries such that their implementation reinforces each other. Fisheries sustainability depends on integration of policies governing a range of diverse activities, e.g., water, agriculture, forests, mining, and tourism. Institutional nomadism, 


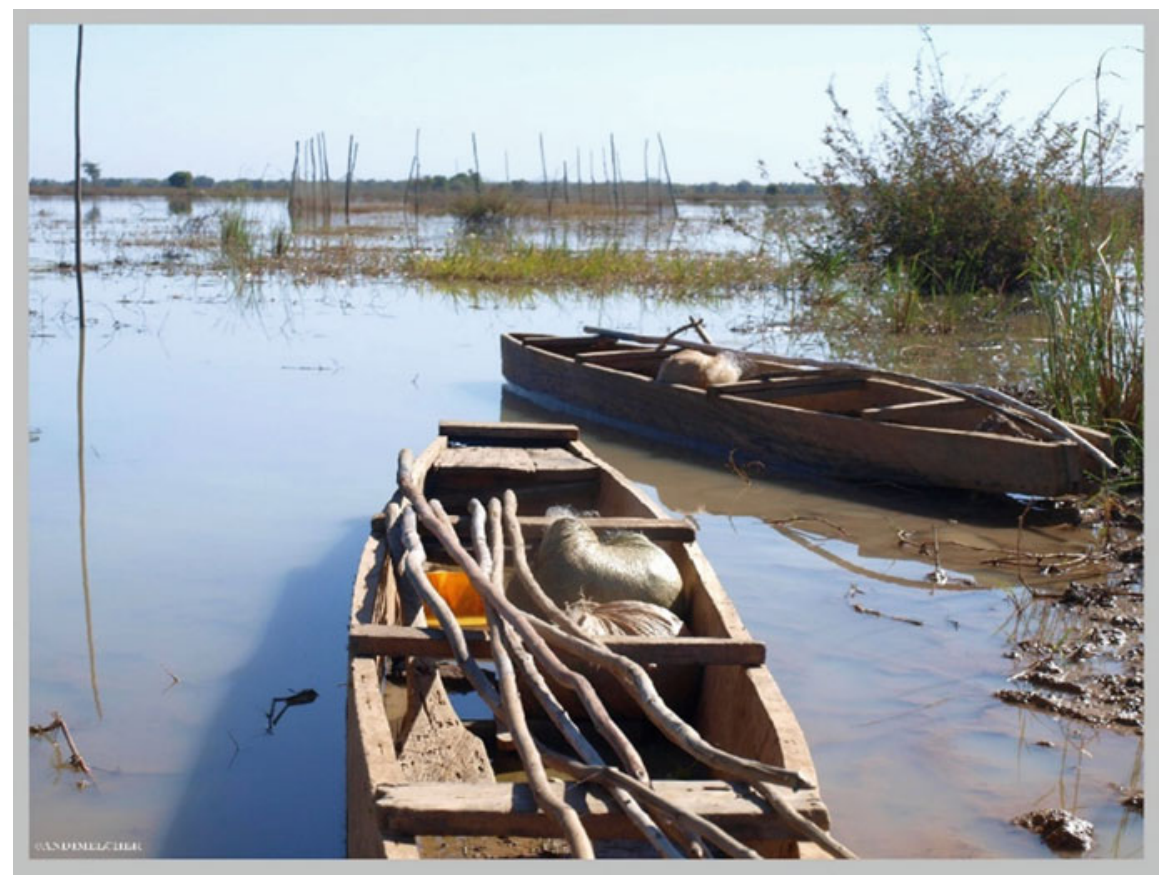

Fig. 27.6 Sustainable fishing in the very dry north of Burkina at the swamps of Dori, close to the border to Mali (Photo: A. Melcher)

the unpredictable shifting of responsibilities between ministries, contributes to this frequent failure to create compatible policies or integrate them. It also promotes interagency conflicts (e.g., agricultural staff vs. foresters) by keeping the boundaries of agency responsibility vague and undefined. Without a clear mandate, field officers are not inclined to monitor fisheries. Some fishermen agree and claim such responsibility shifts prevented surveillance that would have hindered them from using smaller net mesh sizes, a trend driving down fish size. The implications of such unpredictable shifts in responsibility are general feelings of frustration, helplessness, and a lack of trust in governance, which are sustained when such nomadism perpetuates a state of ignorance by those officially responsible for management.

Better harmony can be achieved between national and local levels if local knowledge is better integrated in forming and implementing the visions and resulting policies for sustainable fisheries. So far such input has been blocked by lack of local capacity to constructively participate. The reasons for this lack of capacity are multiple: lack of funding to support participation, lack of experience or training in participation (people), and lack of effective processes of participative democracy (governance). This lack of local organizing capacity hinders efforts for bottom-up leadership in fisheries management to fill the gap left by failure from the top, the national level. Very few, if any local sustainability initiatives are started, is often blocked by the perception that they lack resources, usually money. This lack of 
inclusiveness is reinforced by chronic failure to evaluate policies periodically and improve them. Such periodic policy review requires rigorous measurement of policy impacts and could identify where lack of local involvement harms policy creation or administration. Also such periodic review could be done with mutual contributions from national and local levels, such that policy reform reflects experience from different governance levels.

In the vacuum between national and local governance levels, such governance breakdowns as elite capture are especially harmful and result in resistance of local communities to new regulations. Furthermore, this vacuum isolates and hinders efforts to harmonize the "republican," e.g., European-based democratic, with the traditional institutions. Both make relatively important contributions to the governance of water and fish resources. Despite the ongoing development and refinement of Republican institutions, there has been some resurgence of traditional practices (sacrifice by fishermen, traditional fishing). However, this trend is not universal and in some cases the opposite is true. Traditional stress [conflict] management seems to change or slip away leaving some room for modern management. Traditional institutions reinforce the sense of aquatic ecosystems as "sacred space" at the heart of the life of surrounding communities. "Water bodies occupy an important place in the history of the study area. They are loaded with symbolism and contain very often places of worship."

This failure to harmonize policies across different governance levels is linked to or ineffective efforts to decentralize power to regions while maintaining a functioning governance structure that works across all levels. When officials choose to ignore rather than engage local problems, the lack of engagement gives local fishermen no opportunity to learn about fisheries policies through responding to them. Thus they remain ignorant of legislation administrative policy and other matters in which knowledge is required for proper management. However, this is also a question of adequate training modules for the target groups of managers and practitioners. For instance, some training courses have been developed, but they are not specialized for fishing. Rather they are framed for agriculture in general with a very few sessions for fishing and aquaculture. Furthermore, this training is not generally available across all $\mathrm{BF}$ and not comprehensive or detailed enough to really make a difference.

Long-term sustainability of ecosystems and society in BF is challenged by population growth rates that exceed economic development and environmental carrying capacity. Lowering population growth rates requires the second phase of the demographic transition, which in turn depends on elevating the capacity of women in education and business. The elaboration of a strategy for the integration of a gender-sensitive approach in projects and policies for fisheries will support the participation of female actors in the sector. But as findings showed, the consideration of women's needs and strategic interests is often linked to other policy sectors such as health, nutrition, water management, and education (Fig. 27.7). The coordination and integration of research findings and policy recommendations between the involved ministries are crucial for the development of a comprehensive development plan. 


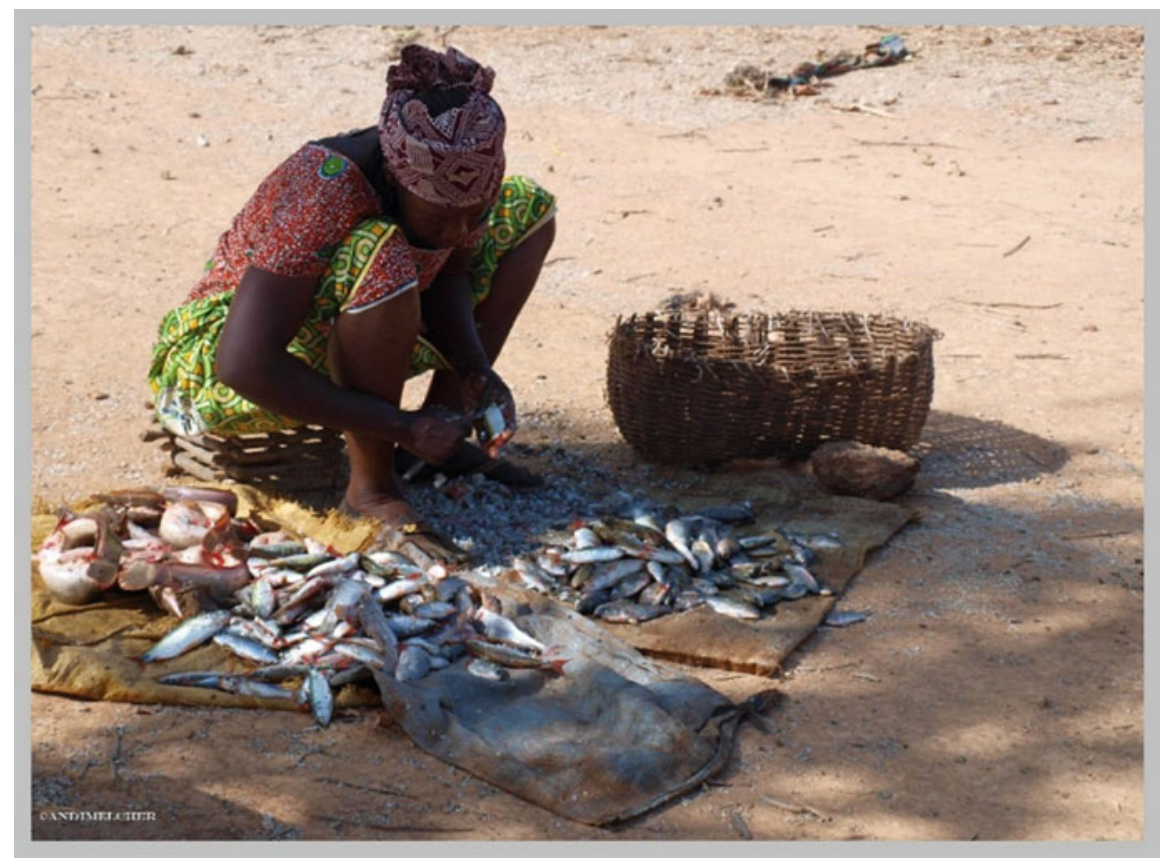

Fig. 27.7 Sustainable fisheries management needs a lot of women power, especially in processing, marketing, and trading fish, like at the market of Koubri close to the capital city Ouagadougou (Photo: A. Melcher)

\section{References}

Aggrey-Fynn J, Galyuon I, Aheto DW, Okyere I (2011) Assessment of the environmental conditions and benthic macroinvertebrate communities in two coastal lagoons in Ghana. Ann Biol Res 2(5):413-424

Batterbury S, Warren A (2001) The African Sahel 25 years after the great drought: assessing progress towards new agendas and approaches. Glob Environ Chang 11(1):1-8

Butterworth DS, Bentley N, De Oliveira JA, Donovan GP, Kell LT, Parma AM, Punt AE, Sainsbury KJ, Smith ADM, Stokes TK (2010) Purported flaws in management strategy evaluation: basic problems or misinterpretations? ICES J Mar Sci 67(3):567-574

Camara IA, Diomande D, Bony YK, Ouattara A, Franquet E, Gourène G (2012) Diversity assessment of benthic macroinvertebrate communities in Banco National Park (Banco Stream, Côte d'Ivoire). Afr J Ecol 50:205-217

Cecchi P, Gourdin F, Kone S, Corbin S, Etienne J, Casenave A (2009) Les petits barrages du Nord de la Côte d'Ivoire: Inventaire et potentialités hydrologiques. Sécheresse 20(11):112-122

Cook SE, Fisher MJ, Giordano M, Andersson MS, Rubiano J (2009) Water, food and livelihoods in river basins. Water Int 34:13-29

DGPSA (2007) Production d'un atlas dynamique sur la sécurité alimentaire du Burkina Faso. Document de projet. Direction Générale des Prévisions et des Statistiques Agricoles. Ministère de l'Agriculture de l'Hydraulique et des Ressources Halieutiques, Février 2007, 8 p

Edia OE, Bony KY, Konan KF, Ouattara A, Gourène G (2013) Distribution of aquatic insects among four costal river habitats (Côte d'Ivoire, West-Africa). Life Sci 2(8):68-77 
Fabio P, Braimah LI, Bortey A, Wadzah N, Cromwell A, Dacosta M, Seghieri C, Salvati N (2003) Poverty profile of riverine communities of southern lake Volta. Sustainable Fisheries Livelihoods Programme in West Africa, Cotonou, 70 p, SFLP/FR/18

Filippi C, Milville F, Thiéry D (1990) Evaluation de la recharge naturelle des aquifères en climat Soudano-Sahelien par modélisation hydrologique globale: application a dix sites au Burkina Faso. Hydrol Sci J 35(1):29-48

IMF (2014) Burkina Faso. Selected issues. IMF (International Monetary Fund) country report no. $14 / 230$. July $2014.35 \mathrm{p}$

INSD (2006) Institut National de la Statistique et de la Démographie. Statistiques de l'environnement. Available online http://www.insd.bf/fr/

IUCN (2016) IUCN red list status. Available online http://www.iucnredlist.org/initiatives/freshwa ter/westafrica/rlwa

Kaboré I (2016) Benthic invertebrate assemblages and assessment of ecological status of water bodies in the Sahelo-Sudanian area (Burkina Faso, West Africa). Doctoral thesis, Doctoral thesise, Institute of Hydrobiology and Aquatic Ecosystem Management (IHG), University of Natural Resources and Life Sciences, Vienna, Austria (BOKU), p 242

Kaboré I, Moog O, Alp M, Guenda W, Koblinger T, Mano K, Ouéda A, Ouedraogo R, Trauner D, Melcher A (2016a) Using macro-invertebrates for ecosystem health assessment in semi-arid streams of Burkina Faso. Hydrobiologia 766(1):57-74

Kaboré I, Jäch MA, Ouéda A, Moog O, Guenda W, Melcher A (2016b) Dytiscidae, Noteridae and Hydrophilidae of semi-arid waterbodies in Burkina Faso: species inventory, diversity and ecological notes. J Biodivers Environ Sci 8(4):1-14

Koblinger S, Trauner D (2014) Benthic invertebrate assemblages in water bodies of Burkina Faso. Master thesis, Institute of Hydrobiology and Aquatic Ecosystem Management (IHG), University of Natural Resources and Life Sciences, Vienna, Austria (BOKU), p 156

Ly M, Traore SB, Agali A, Sarr B (2013) Evolution of some observed climate extremes in the West African Sahel. Weather Clim Extrem 1:19-25

Mano K (2016) Fish assemblages and fish based assessment of the ecological integrity of river networks in Burkina Faso. Doctoral thesis, Institute of Hydrobiology and Aquatic Ecosystem Management (IHG), University of Natural Resources and Life Sciences, Vienna Austria (BOKU), p 244

MECV (2007) Rapport de l'inventaire National des sources de production, d'utilisations et de rejets du mercure dans l'environnement au Burkina Faso Eds: Dir. Gen. Env. Cadre de Vie, Burkina Faso, $84 \mathrm{p}$

MEF (2004) Politique nationale de population au Burkina Faso. Conseil National de Population, Ministère de l'Economie et des Finances, Burkina Faso

Melcher A (2015) Sustainable management of water and fish resources in Burkina Faso. The project—SUSFISH. In: Obrecht AJ (ed) APPEAR. Participative knowledge production through transnational and transcultural academic cooperation. Böhlau, Wien, p 319. ISBN 978-3-20579690

Melcher A, Ouedraogo R, Schmutz S (2012) Spatial and seasonal fish community patterns in impacted and protected semi-arid rivers of Burkina Faso. Ecol Eng 48:117-129

Melcher A, Ouedraogo R, Savadogo M, Sendzimir J (2013) Current questions in sustainable water management and higher education in Burkina Faso. The SUSFISH consortium book of abstracts, West Africa Symposium, Vienna, Austria, 23-28 June 2013. https://doi.org/10. 13140/2.1.1970.8967

Meulenbroek P (2013) Fish assemblages and habitat use in the Upper Nakambe Catchment, Burkina Faso. Master thesis, Institute of Hydrobiology and Aquatic Ecosystem Management (IHG), University of Natural Resources and Life Sciences, Vienna, Austria (BOKU), p 60

Moog O, Stubauer I (2003) Adapting and implementing common approaches and methodologies for stress and impact analysis with particular attention to hydromorphological conditions. Final report, UNDP/GEF DANUBE REGIONAL PROJECT. Strengthening the implementation capacities for nutrient reduction and transboundary cooperation 
MRAH (2013) Stratégie nationale de développement durable de la pèche et de l'aquaculture à l'horizon 2025. Ministère des Ressources Animales et Halieutiques. Adoptée le 18 décembre 2013, Burkina Faso, 35 p

Niasse M, Alejandro I, Amidou G, Olli V (2004) La gouvernance de l'eau en Afrique de l'Ouest: aspects juridiques et institutionnels-Water Governance in West Africa: legal and institutional aspects. UICN, Gland, Suisse et Cambridge, Royaume Uni. xxiv +247 p

Nijboer RC, Jhonson RK, Verdonschot PFM, Sommerhäuser M, Buffagni A (2004) Establishing reference conditions for European streams. Hydrobiologia 516:91-105

Ouedraogo R (2010) Fish and fisheries prospective in arid inland waters of Burkina Faso, West Africa. Doctoral thesis, Institute of Hydrobiology and Aquatic Ecosystem Management (IHG), University of Natural Resources and Life Sciences, Vienna, Austria (BOKU), p 232

Ouedraogo R, Oueda A, Savadog M, Melcher A (2014) Sustainable management of water and fish resources in Burkina Faso-Susfish Péche Eau. The SUSFISH consortium book of abstracts—Recueil des Résumés, Symposium, Ouagadougou 15-16 July 2014, Ouagadougou, Burkina Faso. https://doi.org/10.13140/2.1.3805.9048

Ouedraogo R, Savadogo M, Kabore C, Kabre G, Oueda A, Nianogo A, Peloschek F, Sendzimir J, Slezak G, Toe P, Zerbo H, Melcher A (2015) The SUSFISH project-a trans-disciplinary approach to integrating people, fishery, socio-economy and higher education. In: Obrecht AJ (ed) APPEAR. Participative knowledge production through transnational and transcultural academic cooperation. Böhlau, Wien, p 319. ISBN 978-3-205-79690

Ouedraogo R, Oueda A, Kabore AW, Savadogo M, Zerbo H, Seynou O, Kabore Zanbsore C, Dibloni TO, Laleye P (2016) Liste rouge des poissons du Burkina Faso. UICN Burkina Faso (in print)

Pauly D, Christensen V, Froese R, Palomares MLD (2000) Fishing down aquatic food webs. Am Sci 88:46-51

Pavelic P, Giordano M, Keraita B, Ramesh V, Rao T (2012) Groundwater availability and use in Sub-Saharan Africa: a review of 15 countries. International Water Management Institute (IWMI), Colombo, p 274. https://doi.org/10.5337/2012.213

Pont D, Hugueny B, Beier U, Goffaux D, Melcher A, Noble R, Rogers C, Roset N, Schmutz S (2006) Assessing river biotic condition at a continental scale: a European approach using functional metrics and fish assemblages. J Appl Ecol 43(1):70-80

Raynaut C (1997) Societies and nature in the Sahel, SEI global environment and development series. Routledge, London

Roman B (1966) Les poissons des Haut-Bassins de la Volta. Musée Royal de l'Afrique Centrale, Tervuren

Sendzimir J, Slezak G, Ouedraogo R, Savadogo M, Cecchi P, Kabore C, Kabre G, Magnuszewski P, Oueda A, Nianogo A, Moog O, Peloschek F, Savadogo L, Toe P, Zerbo H, Melcher A (2015) Sustainable management of water and fish resources in burkina faso (SUSFISH) - a synthetic overview of the susfish project—-society meets ecology. Editor: The SUSFISH Consortium, p 80. https://doi.org/10.13140/RG.2.1.5015.2482

Slezak G, Oueda A, Cecchi P, Kabre GB, Moog O, Ouedraogo R, Peloschek F, Savadogo LGB, Schmutz S, Sendzimir J, Toe P, Waidbacher H, Melcher A (2015) The SUSFISH project-joint research and scientific exchange for higher education. In: Obrecht AJ (ed) APPEAR. Participative knowledge production through transnational and transcultural academic cooperation. Böhlau, Wien, p 319. ISBN 978-3-205-79690

Smith KG, Diop MD, Niane M, Darwall WRT (2009) The status and distribution of freshwater biodiversity in Western Africa Gland, Switzerland and Cambridge. IUCN, UK, x + 94 p + 4 p cover

SP/CONAGESE (2001) Communication nationale du Burkina Faso. Convention-Cadre des Nations Unies sur les Changements Climatiques. Adoptée par le gouvernement en novembre $2001,126 \mathrm{p}$ 
Stranzl S (2014) Quantification of human impacts on fish assemblages in the Upper Volta catchment, Burkina Faso. Master thesis, Institute of Hydrobiology and Aquatic Ecosystem Management (IHG), University of Natural Resources and Life Sciences, Vienna, Austria (BOKU), p 90

Thorne R, Williams P (1997) The response of benthic macroinvertebrates to pollution in developing countries: a multimetric system of bioassessment. Freshw Biol 37:671-686

Trauner D, Koblinger T, Huber T, Moog O, Melcher A (2013) Benthic invertebrate assemblages in the Upper Nakambe Basin. In: SUSFISH Consortium Appear Project [56], Current questions in sustainable water management and higher education in Burkina Faso. Book of abstracts. http://susfish.boku.ac.at/. https://doi.org/10.13140/2.1.1970.8967

UNDP (2015) Human development report 2015. Work for human development. United Nations Development Programme 1 UN Plaza, New York, NY 10017, USA

Vinson MR, Dinger EC, Kotynek J, Dethier M (2008) Effects of oil pollution on aquatic macroinvertebrate assemblages in Gabon wetlands. Afr J Aquat Sci 33:261-268

Wang L, Dochartaigh OB, Macdonald D (2010) A literature review of recharge estimation and groundwater resource assessment in Africa. British Geological Survey Internal Report, IR/10/051, $31 \mathrm{p}$

Zerbo H, Ouattara DC, Soubeiga Z, Kabore K, Kabore C, Bado E, Goumbri BA, Yerbanga RA, Ouedraogo N, Baro S (2007) Analyse de la filière pêche au Burkina Faso. Projet d'Appui au Renforcement des Capacités d'Analyse des Impacts des Politiques Agricoles. Direction Générale des Ressources Halieutiques. Ministère de l'Agriculture, de l'Hydraulique et des Ressources Halieutiques. Août 2007, 63 p

Open Access This chapter is licensed under the terms of the Creative Commons Attribution 4.0 International License (http://creativecommons.org/licenses/by/4.0/), which permits use, sharing, adaptation, distribution and reproduction in any medium or format, as long as you give appropriate credit to the original author(s) and the source, provide a link to the Creative Commons license and indicate if changes were made.

The images or other third party material in this chapter are included in the chapter's Creative Commons license, unless indicated otherwise in a credit line to the material. If material is not included in the chapter's Creative Commons license and your intended use is not permitted by statutory regulation or exceeds the permitted use, you will need to obtain permission directly from the copyright holder.

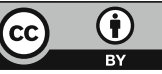

